\title{
World Tobacco Quitting Day 2020 - the united voice of Polish experts on tobacco prevention and control
}

\author{
Paweł Koczkodaj ${ }^{1}$, Joanna Didkowska ${ }^{1,2}$, Łukasz Balwicki ${ }^{3}$, Magdalena Cedzyńska', \\ Marzena Dominiak ${ }^{4,5}$, Wojciech Hanke, ${ }^{6,}$, Piotr Jankowski ${ }^{8}$, Jacek Jassem ${ }^{9}$, Grzegorz Juszczyk ${ }^{10,11}$, \\ Maciej Krzakowski12, Jarosław Pinkas ${ }^{13,14}$, Irena Przepiórka' , Krzysztof Przewoźniak1, \\ Piotr Rutkowski15, 16 , Daniel Śliż ${ }^{17}$, Stefan Wesołowski ${ }^{18}$, Tomasz Zdrojewski ${ }^{19}$, Jan Walewski20
}

\author{
'Department of Epidemiology and Primary Cancer Prevention, Maria Sklodowska-Curie National Research Institute of Oncology, Warsaw, Poland \\ ${ }^{2}$ National Cancer Registry, Maria Sklodowska-Curie National Research Institute of Oncology, Warsaw, Poland \\ ${ }^{3}$ Department of Public Health \& Social Medicine, Medical University of Gdansk, Poland \\ ${ }^{4}$ Department of Oral Surgery, Wroclaw Medical University, Poland \\ ${ }^{5}$ Polish Dental Society, Wroclaw, Poland \\ ${ }^{6}$ Department of Environmental Epidemiology, Nofer Institute of Occupational Medicine in Lodz, Poland \\ 7 Public Health Committee, Polish Academy of Science, Warsaw, Poland \\ ${ }^{8}$ Department of Cardiology, Interventional Electrocardiology and Hypertension, Institute of Cardiology, Jagiellonian University Medical College, Krakow, Poland \\ ${ }^{9}$ Department of Oncology and Radiotherapy at the Medical University of Gdansk, Poland \\ ${ }^{10}$ National Institute of Public Health-National Institute of Hygiene, Warsaw, Poland \\ "Department of Public Health, Medical University of Warsaw, Poland \\ ${ }^{12}$ Department of Lung Cancer and Thoracic Tumors, Maria Sklodowska-Curie National Research Institute of Oncology, Warsaw, Poland \\ ${ }^{13}$ Chief Sanitary Inspectorate of the State Sanitary Inspection, Warsaw, Poland \\ ${ }^{14} \mathrm{~S} c h o o l$ of Public Health, Centre of Postgraduate Medical Education, Warsaw, Poland \\ ${ }^{15}$ Department of Soft Tissue/Bone Sarcoma and Melanoma, Maria Sklodowska-Curie National Research Institute of Oncology, Warsaw, Poland \\ ${ }^{16} \mathrm{Committee} \mathrm{for} \mathrm{the} \mathrm{National} \mathrm{Oncological} \mathrm{Strategy,} \mathrm{Ministry} \mathrm{of} \mathrm{Health,} \mathrm{Warsaw,} \mathrm{Poland}$ \\ $173^{\text {rd }}$ Department of Internal Diseases and Cardiology, Medical University of Warsaw, Poland \\ ${ }^{18}$ National Institute of Tuberculosis and Lung Diseases, Warsaw, Poland \\ ${ }^{19}$ Department of Preventive Medicine and Education, Medical University in Gdansk, Poland \\ ${ }^{20}$ Department of Lymphoid Malignancies, Maria Sklodowska-Curie National Research Institute of Oncology, Warsaw, Poland
}

On November $19^{\text {th }}, 2020$ we will celebrate annual World Tobacco Quitting Day. On this occasion, we would like call to action for a stronger and united tobacco prevention activities in Poland.

Despite many successes in tobacco prevention and control, use of tobacco products in Poland is still a great public health challenge. Whereas the prevalence of traditional cigarettes smoking is declining, new tobacco products are more and more popular - particularly among young people. It has been estimated that about $28 \%$ of boys and
$18.6 \%$ of girls aged $13-15$ years in Poland use e-cigarettes. Moreover, in the same age group $15.6 \%$ of boys and $14.9 \%$ of girls smoke traditional cigarettes [1]. Considering adult population, e-cigarettes are less popular - about $4 \%$ of men and about $1 \%$ of women use this particular tobacco product [2]. However, the use of traditional cigarettes is much higher - $26 \%$ and $17 \%$ of Polish men and women, respectively, are regular smokers [3].

Being aware of overwhelming influence of SARS-CoV-2 pandemic on health care systems, we cannot ignore impact

\section{How to cite:}

Koczkodaj P, Didkowska J, Balwicki Ł, Cedzyńska M, Dominiak M, Hanke W, Jankowski P, Jassem J, Juszczyk G, Krzakowski M, Pinkas J, Przepiórka I, Przewoźniak K, Rutkowski P, Śliż D, Wesołowski S, Zdrojewski T, Walewski J. World Tobacco Quitting Day 2020 - the united voice of Polish experts on tobacco prevention and control. NOWOTWORY J Oncol 2020; 70: 278-279. 
of other pandemic, which lasts for decades and is evolving just in front of our eyes. Only between 2011 and 2014, e-cigarettes use among young Poles has increased from 6\% to 29.9\% [4]. Compared to other EU-countries, Poland has one of the highest rates of e-cigarettes use among teenagers [1]. Moreover, Poland is among a few European Union (EU) countries with a very high level (17.5\% to <20\%) of tobacco attributable Disability-Adjusted Life Years (DALYs) [5]. For comparison, Romania and Czech Republic are in the group of countries with DALY between $15 \%$ to $<17.5 \%$, Germany and Spain $12.5 \%$ to $<15 \%$, and France and Italy $10 \%$ to $<12.5 \%$.

Considering these data, we appeal to all involved parties - researchers, health professionals, and stakeholder and policymakers to advocate for a stronger and more tailored anti tobacco law, health education and stable long lasting financing of such actions. We believe that we need to stand together to stop, or at least to slow down tobacco epidemic in Poland.

Conflict of interest: none declared

\section{Paweł Koczkodaj}

Maria Sklodowska-Curie National Research Institute of Oncology Cancer Epidemiology and Primary Prevention Department ul. Wawelska $15 B$

02-034, Warszawa, Poland

e-mail:pawel.koczkodaj@pib-nio.pl

Received and accepted: 6 Nov 2020

\section{References}

1. Centers for Disease Control and Prevention. National Center for Chronic Disease Prevention and Health Promotion, Office of Smoking and Health, Global Tobacco Surveillance System Data (GTSSData). https:// www.cdc.gov/tobacco/global/gtss/gtssdata/index.html (2.11.2020).

2. Trząsalska A, Staszyńska M, Krassowska U. Raport z ogólnopolskiego badania ankietowego na temat postaw wobec palenia tytoniu. Kantar Public dla Głównego Inspektoratu Sanitarnego, Warszawa 2017.

3. Centrum Badań Opinii Społecznej. Komunikat z Badań nr 104/2019. Palenie papierosów. 2019; sierpień.

4. Balwicki L, Smith D, Balwicka-Szczyrba M, et al. Youth Access to Electronic Cigarettes in an Unrestricted Market: A Cross-Sectional Study from Poland. Int J Environ Res Public Health. 2018; 15(7), doi: 10.3390/ ijerph15071465, indexed in Pubmed: 29997350.

5. Murray C, Aravkin A, Zheng P, et al. Global burden of 87 risk factors in 204 countries and territories, 1990-2019: a systematic analysis for the Global Burden of Disease Study 2019. The Lancet. 2020; 396(10258): 1223-1249, doi: 10.1016/s0140-6736(20)30752-2. 